\title{
An Antisense Construct Reduces N-Methyl- D-Aspartate Receptor 2A Expression and Receptor-Mediated Excitotoxicity as Determined by a Novel Flow Cytometric Approach
}

\author{
Pierre A. Mattar, Kevin D. Holmes, and Gregory A. Dekaban \\ BioTherapeutics Research Group, The John P. Robarts Research Institute, London, Ontario, Canada and \\ Department of Microbiology and Immunology, The University of Western Ontario, London, Ontario, Canada
}

The $N$-methyl-D-aspartate receptor (NMDAR) is a major neurotransmitter receptor in the central nervous system (CNS), with functional roles in learning, memory, and sensation. Several mechanisms potentiate NMDARs, and NMDAR hyperexcitability plays pathophysiological roles in many conditions, such as neurodegenerative disease, ischemia, and chronic conditions arising from spinal cord injury. Previous research suggests that the NR2A subunit of the receptor contributes to NMDAR excitotoxicity in heterologous cells and in neurons in vivo. To investigate the role of NR2A in NMDAR excitotoxicity, we have developed a system based on flow cytometry that allows rapid evaluation of the effect of antisense constructs on protein expression and channel function. The enhanced yellow fluorescent protein (EYFP) was fused to obligatory NMDAR subunits, allowing expression to be monitored in living cultured cells. An NR2A antisense construct, asNR2A, specifically and effectively reduced NR2A-EYFP expression. NR1 and NR2A fusion proteins formed functional, excitotoxic channels upon co-expression. The asNR2A RNA significantly reduced NMDAR excitotoxicity when NR2A levels were limiting for channel formation. Using our assay system, further optimization can be achieved rapidly. The asNR2A construct and the assays developed for this study can be used to provide insights into NMDAR biology and disease. $\odot 2003$ Wiley-Liss, Inc.

Key words: antisense; excitotoxicity; flow cytometry; green fluorescent protein; $N$-methyl-D-aspartate receptor

The N-methyl-D-aspartate receptor (NMDAR) forms an ion channel that opens in response to the co-agonists glutamate and glycine (Ozawa et al., 1998). NMDARs are widespread throughout the central nervous system (CNS) and peripheral nervous system (PNS) (Ozawa et al., 1998), and are also expressed several nonneuronal cell types (Inagaki et al., 1995; Chenu et al., 1998; Lombardi et al., 2001). As well as participating in many sensory processes (Minami et al., (c) 2003 Wiley-Liss, Inc.
1997), NMDARs play crucial roles in learning and memory (Sprengel and Single, 1999). At the molecular level, NMDARs are thought to "remember" prior stimuli via a process called long-term potentiation (LTP; Bliss and Collingridge, 1993; Malenka and Nicoll, 1999). In the hippocampus, NMDARs that are stimulated appropriately cause an influx of calcium ions that leads to a localized activation of calcium/ calmodulin-dependent kinase II (CaMKII). CaMKII then potentiates the local AMPA ( $\alpha$-amino-3-hydroxy5-methyl-4-isoxazoleproprionic acid) receptors, leading to a long-lasting enhancement of the glutamatergic neurotransmission at a given synapse (Malenka and Nicoll, 1999). In addition to CaMKII, several other NMDAR-activated signal transduction pathways have been implicated in LTP, including casein kinase II, cyclic AMP-dependent protein kinase, protein kinase $\mathrm{C}$, mitogen-activated protein kinase, and Src (Lieberman and Mody, 1999; Malenka and Nicoll, 1999; Sheng and Kim, 2002).

Perhaps because of the many calcium-activated positive feedback loops that regulate NMDARs, it is no surprise that excessive NMDAR activity seems to play pathophysiological roles in several diseases and clinical conditions. Exaggerated NMDAR activity may play a role in some forms of epilepsy (Kohl and Dannhardt, 2001). Also, NMDAR-mediated excitotoxicity exacerbates a number of neurodegenerative diseases (Doble, 1999), as well as ischemia, hypoxia, and CNS trauma (Faden et al.,

Contract grant sponsor: Heart and Stroke Foundation of Canada; Contract grant number: NA4889; Contract grant sponsor: Canadian Institutes of Health Research.

^Correspondence to: Gregory A. Dekaban, Ph.D., BioTherapeutics Research Group, The John P. Robarts Research Institute, P.O. Box 5015, 100 Perth Drive, London, Ontario N6A 5K8, Canada. E-mail: Dekaban@robarts.ca

Received 23 April 2003; Revised 22 July 2003; Accepted 23 July 2003 
1989; Nishizawa, 2001). NMDARs are involved in chronic pain syndromes (Minami et al., 1997; Eide, 1998; Hewitt, 2000) and the hyperexcitability of spinal neurons mediating autonomic dysreflexia (Maiorov et al., 1997) that are prevalent in victims of spinal cord injury.

NMDARs are formed by two essential subunits, the NR1 subunit, which is expressed from a single gene, and the NR2 subunits, which are expressed from four genes, NR2A-D (Dingledine et al., 1999). A third nonobligatory type of NMDAR subunit, NR3, is restricted to small neuronal subsets in the adult CNS (Ciabarra et al., 1995; Nishi et al., 2001; Sasaki et al., 2002). Although NR2 subunits have much longer half-lives than NR1 subunits (Huh and Wenthold, 1999; Garcia-Gallo et al., 2001; Vazhappily and Sucher, 2002), NR2 mRNA and protein levels are much more modest in comparison to NR1 levels (Goebel and Poosch, 1999; Garcia-Gallo et al., 2001). Thus, NR2 subunits are limiting for channel formation in neurons (Huh and Wenthold, 1999; Prybylowski et al., 2002). Electrophysiological properties of NMDARs, such as the strength of $\mathrm{Mg}^{2+}$ blockade and current density, are also dependent on the NR2 component of a given receptor (Cull-Candy et al., 2001). NR2 subunits also contribute differentially to disease pathology. The NR2A subunit leads to the NMDAR with the fastest kinetics (Monyer et al., 1994), and is the most excitotoxic of the NR2 subunits in cell culture models (Anegawa et al., 1995, 2000). NR2A has been implicated genetically in the pathology of spinal chronic pain syndromes and ischemia (Minami et al., 1997; Morikawa et al., 1998). Thus, NR2 subunits, and the NR2A subunit in particular, may be important targets for therapeutic intervention in diseases associated with NMDAR excitotoxicity and hyperexcitability. Accordingly, we have chosen to develop an antisense construct targeting the NR2A subunit to examine its pathological role in NMDAR hyperexcitability and excitotoxicity.

Typically, antisense constructs are evaluated initially using methods that track changes in target mRNA expression. Supplementary experiments must be carried out to confirm that effective constructs cause a corresponding reduction in protein levels, and that the resultant reductions are functionally significant. Although several techniques have been developed to aid the prediction of effective antisense constructs (e.g., Xing and Whitton, 1992; Zhao and Lemke, 1998), the generation of effective antisense constructs remains largely a matter of trial and error (e.g., Jarvis et al., 1996; Pierce and Ruffner, 1998; Tatout et al., 1998; Yu et al., 1998; Wrzesinski et al., 2000; Lloyd et al., 2001; Sohail et al., 2001, but see Scherr et al., 2000). Accordingly, we have created an in vitro system that allows such therapeutic agents to be evaluated rapidly. This system uses flow cytometry to monitor expression of fluorescently tagged NMDAR subunits and uses excitotoxicity to monitor excessive NMDAR function. Using this novel approach, we demonstrate that an antisense construct can effectively reduce NR2A expression and the resultant NMDAR-mediated excitotoxicity.

\section{MATERIALS AND METHODS}

\section{Polymerase Chain Reaction}

All polymerase chain reactions (PCRs) were prepared in a dedicated hood with analytical pipettes for reagents, and a separate Gilson Microman pipette (Villiers-le-Bel, France) with a disposable piston/tip system for template DNA only. PCR reagents and primers were obtained from Invitrogen (Burlington, $\mathrm{ON}$ ) and used according to the manufacturer's instructions. All PCR reactions were sequenced to check the fidelity of amplification.

\section{Reverse Transcription-PCR}

Cells expressing the desired constructs were harvested using Trizol reagent (Invitrogen) according to the manufacturer's instructions. The quality and yield of the RNA was checked using spectrophotometry and agarose gel electrophoresis to visualize $28 \mathrm{~S}$ and $18 \mathrm{~S}$ ribosomal RNA. Reverse transcriptase reactions (RT) were carried out using the Thermoscript Reverse Transcriptase-PCR System (Invitrogen) according to the manufacturer's instructions. For each RT reaction, $1 \mu \mathrm{g}$ of RNA, obtained from the entire transfected culture, was added to either the sense or antisense primer at a concentration of $10 \mu \mathrm{M}$. To ensure that no DNA contaminated the RNA samples used in the RT-PCR, each RNA sample was incubated with DNase I for $60 \mathrm{~min}$ at $37^{\circ} \mathrm{C}$. The enzyme was inactivated by incubating samples at $65^{\circ} \mathrm{C}$ for $30 \mathrm{~min}$, in concert with subsequent chloroform extraction of the RNA. To ensure that no DNA survived this treatment, the unadulterated RNA samples were also subjected to PCR amplification. The following primers were used to prime reverse transcription of sense or antisense NR2A RNA, as well as for the subsequent PCR: sense primer GGCTACTGGACCTTGCTGGTATTGC; antisense primer CAGCCTCCTGGTCCGTGTCATCTC. These primers flank a 312-base pair (bp) region from bases 28-340 of the Nakanishi NR2A sequence (GenBank accession number D13211; Ishii et al., 1993). The following primers were used to amplify sense and antisense NR2D RNA, as well as for the subsequent PCR: sense primer GGAAGTGAGATTGTATGTGTGAG; antisense primer CCAATGGCTCGTGTGTATG. These primers flank a $167-\mathrm{bp}$ region within the $5^{\prime}$ untranslated region (UTR) of NR2D.

\section{Clone Construction}

Several plasmids served as raw materials for clone construction (Fig. 1A). Rattus norvegicus NR2A and NR2D cDNAs and their corresponding sequence data were obtained from Dr. S. Nakanishi (Kyoto University; Kyoto, Japan). NR1-4 and NR1-4-enhanced green fluorescent protein (EGFP) fusion constructs have been described previously (Holmes et al., 2002a) from cDNAs obtained initially from S. Nakanishi, as well as a NR1-1-green fluorescent protein (GFP) fusion protein obtained from $T$. Hughes (Yale University; New Haven, CT). The Aequoria victoria enhanced yellow fluorescent protein vector pEYFP-N1 and the Discosoma sp. fluorescent protein vector pDsRed1-N1 were obtained from Becton Dickinson Biosciences (Mississauga, $\mathrm{ON})$, and pcDNA3 was obtained from Invitrogen. The plasmids pHex 5000, pHex 9000, and pHex 9300 were obtained from C. A. Strathdee (Immunex Corporation, Seattle, WA). 
A
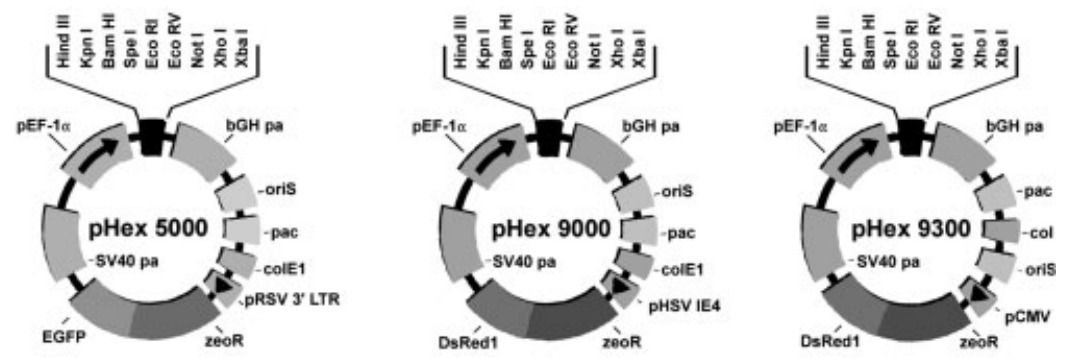

B

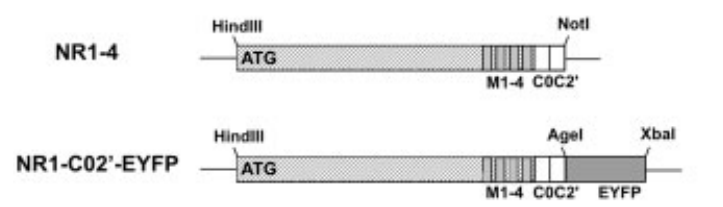

C

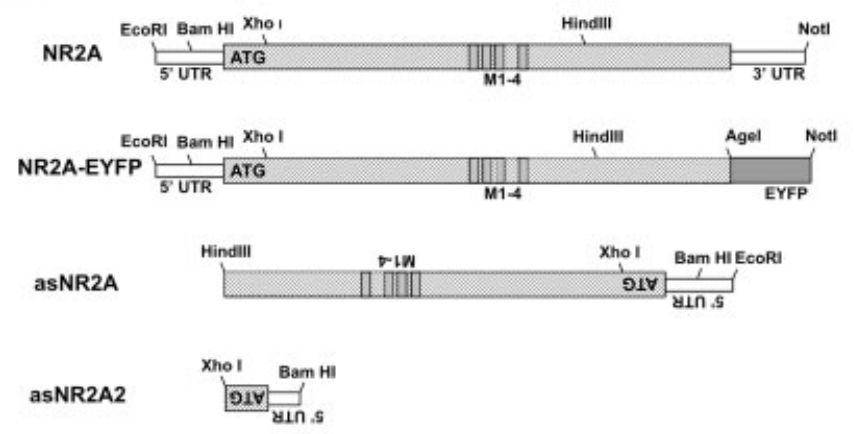

D

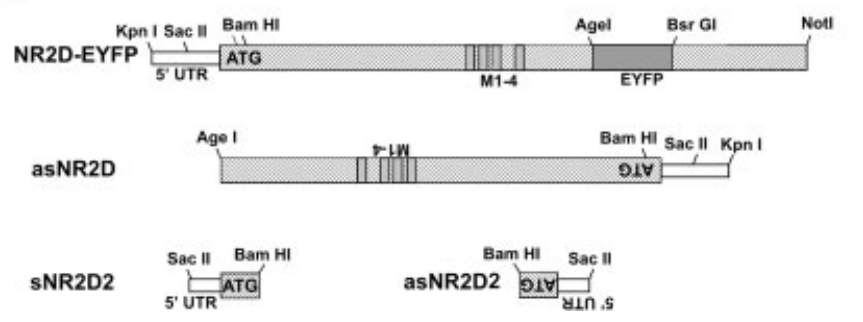

pHex 9000
PEYFP-N1

pHex 5000

pHex 9000

Expression

Vector

pHex 9000

PEYFP-N1

pHex 5000 pHex 9000

pHex 9000
Fig. 1. Constructs used in this investigation. A: pHex expression vectors used for marking transfected cells. These vectors were developed by Dr. C. Strathdee (Immunex Corporation; Seattle, WA), and contain the HSV-1 origin of replication (ori) and packaging (pac) elements. Each vector can express a construct inserted into the indicated multiple cloning site (MCS) under the control of the elongation factor- $1 \alpha$ promoter $(\mathrm{pEF}-1 \alpha)$. Additionally, each vector co-expresses a fluorescent fusion protein consisting of either EGFP or DsRed1 fused to the bleomycin resistance protein. NR1-4 (B), NR2A (C), and NR2D (D) constructs were developed using the indicated restriction endonuclease sites, and expressed using the indicated vector backbone. Both pEYFP-N1 and pcDNA3 vectors express constructs under the regulation of the cytomegalovirus immediate early promoter (pCMV).
Constructs were developed using naturally occurring restriction endonuclease sites, or sites introduced via recombinant PCR technology, as indicated in Figure 1B-D. Restriction endonucleases were supplied by Invitrogen or New England Biolabs (Beverley, MA).

\section{Cell Culture, Transfection, Epifluorescence Microscopy, and Stable Cell Line Production}

Procedures for culture, transfection, epifluorescence microscopy, and stable cell line production using the human embryonic kidney 293 cell line have been described previously (Holmes et al., 2002a,b). All cell culture and transfection reagents were obtained from Invitrogen.

\section{NMDAR Antagonists}

To block NMDAR excitotoxicity, the competitive antagonist DL-2-amino-5-phosphonovaleric acid (APV; Sigma, St. Louis, MO) and the noncompetitive antagonist ketamine (Sigma) were used at concentrations up to $100 \mu \mathrm{M}$ and were added to the culture medium within $16 \mathrm{hr}$ posttransfection, before significant transgene expression had occurred.

\section{Flow Cytometry}

Cells were harvested via brief trypsinization and collected into $1.5-\mathrm{ml}$ tubes, which were centrifuged gently at $1,000 \mathrm{rpm}$ for $5 \mathrm{~min}$ at $4^{\circ} \mathrm{C}$. The cell pellet was resuspended in DMEM medium with no phenol red. When necessary, the cells were 
filtered through 40- $\mu \mathrm{m}$ filters (BD Biosciences; Mississauga, $\mathrm{ON})$. The cells were then transferred to 5-ml polystyrene tubes (BD Biosciences), and maintained on ice. Cells harvested in this way were then analyzed using a FACScan flow cytometer and Cellquest software (BD Biosciences; excitation $\lambda=488 \mathrm{~nm}$ ) using the FL1 (emission $\lambda=519 \mathrm{~nm}$ ) or FL2 (emission $\lambda=$ $565 \mathrm{~nm})$ channels.

Transfection efficiencies for each pHex 9000 construct in both NR2A-EYFP and NR2D-EYFP stable cell lines were determined via flow cytometry as the percentage of cells expressing DsRed1 in the transfected culture. The mean percent DsRed1 expression ( \pm SEM) in stable NR2A-EYFP cells $(n=$ 12) was $14.4 \pm 2.8$ for $\mathrm{pHex} 9000,3.2 \pm 0.4$ for asNR $2 \mathrm{~A}$, and $2.6 \pm 0.4$ for asNR2D. Similarly, in stable NR2D-EYFP cells $(n=14)$, the mean percent DsRed1 expression was $26.5 \pm 1.5$ for pHex 9000, $8.8 \pm 0.8$ for pHex 9000 asNR2A, and $8.1 \pm$ 0.8 for pHex 9000 asNR2D.

Statistical analyses consisted of one-way ANOVA in concert with Tukey's multiple comparison test, and were carried out using GraphPad Prizm 3.0 (GraphPad Inc., San Diego, CA). Where applicable, data are presented as means with the standard error of the mean ( \pm SEM).

\section{Protein Half-Life Determination}

Stable cell lines were treated with cycloheximide (100 $\mu \mathrm{g} / \mathrm{ml}$ final concentration; Calbiochem, La Jolla, CA) suspended in phosphate-buffered saline (PBS; $137 \mathrm{mM} \mathrm{NaCl}$, $2.7 \mathrm{mM} \mathrm{KCl}, 10 \mathrm{mM} \mathrm{Na}_{2} \mathrm{HPO}_{4}$, and $2 \mathrm{mM} \mathrm{KH}_{2} \mathrm{PO}_{4}, \mathrm{pH}$ 7.4). Cells were then subjected to flow cytometry to measure the decay in protein fluorescence over time. Cell viability was tracked using the vital stain propidium iodide (PI; BD Biosciences). Protein decay values were fitted with exponential regression curves using MS Excel (Microsoft Corp., Mississauga, $\mathrm{ON})$ software. The protein half-life was calculated as: $\mathrm{T}_{1 / 2}=$ $0.69 / \mathrm{K}$ where $\mathrm{Y}=\operatorname{span}\left(\mathrm{e}^{-\mathrm{K} x}\right)+$ plateau.

\section{Protein Characterization}

The use of sodium dodecyl sulfate-polyacrylamide gel electrophoresis (SDS-PAGE) to analyze protein has been described previously (Laemmli, 1970; Holmes et al., 2000). The following antibodies were used: mouse monoclonal anti-NR1 (clone 54.1; BD Biosciences) diluted 1:400 in BLOTTO; rabbit polyclonal anti-NR2A (AB1555; Chemicon, Temecula, CA) diluted 1:1,000 in BLOTTO; goat polyclonal anti-NR2D (sc1471; Santa Cruz, Santa Cruz, CA) diluted 1:100 in a caseinbased blocking reagent (Boehringer Mannheim, Burlington, $\mathrm{ON})$. Secondary antibodies consisted of $\left(\mathrm{Fab}^{\prime}\right)_{2}$ horseradish peroxidase (HRP)-conjugated goat anti-mouse, donkey anti-goat, or goat anti-rabbit IgG (Jackson ImmunoResearch; West Grove, PA), diluted 1:5,000 in block. Co-immunoprecipitation was carried out as described previously (Holmes et al., 2002a) using $2 \mu \mathrm{g}$ of a rabbit anti-NMDA $\epsilon 1$ antibody (sc-9056; Santa Cruz) and $20 \mu \mathrm{l}$ of Protein-G Plus-Agarose suspension (Oncogene Research Products, Boston, MA).

\section{RESULTS}

\section{NMDAR Subunit-EYFP Fusion Proteins Express,} Fluoresce, and Are Stable

To visualize the expression, turnover, and function of NMDARs in living cells, we developed several EYFP
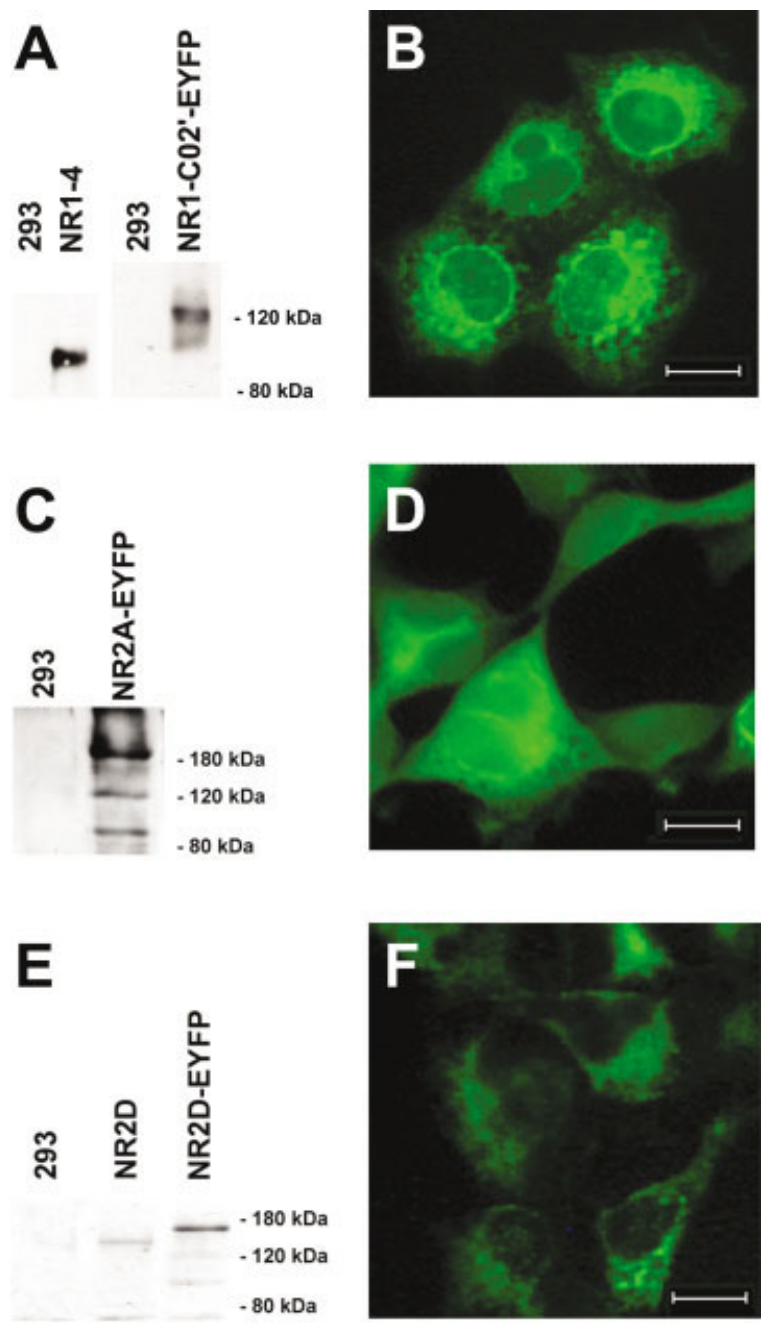

Fig. 2. Expression of NMDAR subunit-EYFP fusion constructs. Stable 293 cell lines expressing NR1-C02'-EYFP (A), NR2A-EYFP (C), or NR2D-EYFP (E) were developed and analyzed using SDS-PAGE/ Western blotting. pHex 9300 NR1-4 (A) and NR2D (E) were expressed transiently in 293 cells as controls. Epifluorescence microscopy was used to visualize the NR1-C02'-EYFP (B), NR2A-EYFP (D), or NR2D-EYFP (F) stable cell lines. Scale bar $=10 \mu \mathrm{m}$.

fusion proteins. HEK 293 cells were chosen for this study as they have been used previously to characterize recombinant NMDAR subunit properties, including ion channel expression and function and assessment of NMDARmediated excitotoxicity (Marshall et al., 1995, Wagey et al., 2001). Recombinant NR1-4-EGFP fusion proteins have been described previously (Holmes et al., 2002a), but were altered by substituting the EYFP protein moiety for EGFP (Fig. 1B). We made a simple, C-terminal fusion of EYFP to the full-length NR2A (Fig. 1C) to yield the construct NR2A-EYFP. The construct NR2D-EYFP contains the EYFP moiety inserted within the intracellular C-terminal domain (Fig. 1D). All of these constructs were expressed, and fluoresced upon stable transfection into 293 cells (Fig. 2). The lower molecular weight bands for NR1-C02'-EYFP, NR2A-EYFP, and NR2D-EYFP 
represent degradation products as reported previously by us and others (Guttmann et al., 2001, Holmes et al., 2002, Wang et al., 2002). The distribution of our NR2A-EYFP construct in 293 cells was very similar to that of an N-terminally tagged GFP-NR2A reported by Luo et al. (2002) and others using different techniques (Huh and Wenthold, 1999; Fukaya et al., 2003). SDS-PAGE and Western blotting confirmed that proteins of the expected molecular weight were expressed successfully from these cell lines (Fig. 2).

The recombinant fusion proteins developed should behave identically to their parental native proteins provided that the addition of the EYFP moiety: (1) did not destabilize the protein; and (2) did not interfere with requisite protein-protein interactions either through steric hindrance or conformational change. To address the first point, we assessed the stability of the recombinant fusion proteins by using cycloheximide to block protein synthesis for varying amounts of time. This allowed the protein half-lives of the various constructs to be quantified using flow cytometry to track the change in EYFP fluorescence over time. Cytotoxicity associated with this treatment was monitored using the vital stain PI. Figure 3 displays the results of this analysis. The half-life of NR1-C02'-EYFP was $4.0 \mathrm{hr}$ as determined by flow cytometry $\left(\mathrm{R}^{2}=0.95\right.$, $n=3$ ). This value is similar to the previously reported value for NR1C0C2'EGFP determined via SDS-PAGE (Holmes et al., 2002a), and for $\mathrm{C}^{\prime}$ cassette-containing NR1 (Huh and Wenthold, 1999). The half-life of NR2AEYFP was calculated to be $9.0 \mathrm{hr}\left(\mathrm{R}^{2}=0.97, n=4\right)$, whereas NR2D-EYFP exhibited a half-life of $11.9 \mathrm{hr}$ $\left(\mathrm{R}^{2}=0.9, n=3\right)$. These turnover rates are similar to the value reported previously (16 $\pm 5 \mathrm{hr}$ ) for the native NR2 subunit NR2A (Huh and Wenthold, 1999).

\section{Antisense NR2A Significantly Reduces NR2A- EYFP Expression}

Antisense constructs targeting NR2A and NR2D were generated using simple directional cloning techniques (Fig. 1C,D). We focused on the region flanking the NR2A and NR2D start codons, as inclusion of the start codon can interfere with translation initiation and elongation in addition to the other, more typical mechanisms of antisense-mediated expression interference (Baker and Monia, 1999; Crooke, 1999). Although asNR2A and asNR2D consisted of large, $\sim 3.5-\mathrm{kb}$ segments of their respective cDNA, the asNR2A2 and asNR2D2 constructs were smaller and targeted more specifically to the region surrounding the start codon. asNR2A2 was generated from a $\sim 800-b p$ segment of the NR2A cDNA, and asNR2D2 was generated from a $\sim 400$-bp segment of the NR2D cDNA. The latter cassette was also cloned in sense orientation as a control (sNR2D2). These antisense constructs were expressed from the pHex 5000 or pHex 9000 vectors. The vector pHex 5000 co-expresses EGFP, a green fluorescent marker, whereas pHex 9000 coexpresses the red fluorescent marker DsRed1.

Control 293 cells and 293 cells stably expressing NR2A-EYFP or NR2D-EYFP were transfected with pHex 9000 asNR2A and asNR2D constructs. RT-PCR
A

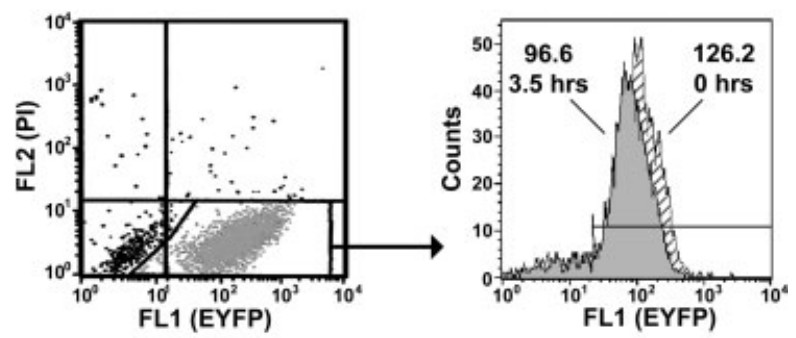

B

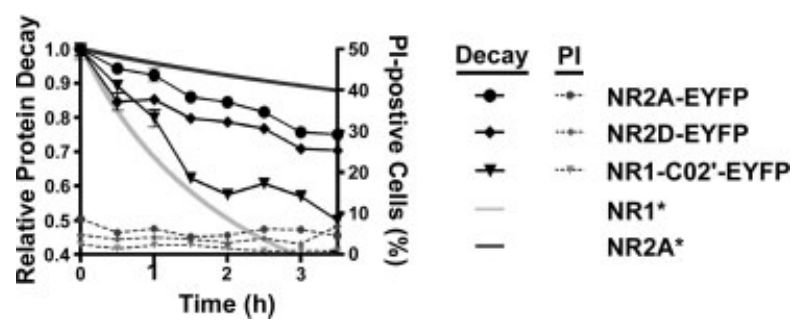

Fig. 3. Flow cytometric quantification of protein turnover. Stable cell lines were treated with $100 \mu \mathrm{g} / \mathrm{ml}$ of the protein synthesis blocker cycloheximide for varying periods of time. As exemplified for NR2AEYFP cells (A), cells were harvested and incubated with PI to mark nonviable cells (positive in the FL2 channel). EYFP-positive, PInegative cells were gated, and the mean EYFP (FL1) fluorescence intensity of the gated cells was calculated (displayed in the histogram; arbitrary units). These values were normalized for fluorescence intensity (maximum fluorescence intensity $=1.0$; untransfected 293 cells $=0$ ). The decay of the normalized mean fluorescence intensity over time was plotted for each stable cell line (see legend; B), and protein half-lives were calculated from the resultant regression curves (see text). The percentage of PI-positive cells detected for each time point is also displayed in the graph. Error bars $=$ SEM $(\star$ from Huh and Wenthold, 1999).

was carried out on the entire population of cells within the transfected culture to confirm that both asNR2A and asNR2D were expressed at the RNA level (Fig. 4A,B). Expression of the 5'UTR of NR2D was also confirmed, which demonstrated that the target NR2D mRNA included this region. The presence or absence of the $5^{\prime} \mathrm{UTR}$ of NR2A could not be confirmed as RT-PCR of this region generated confounding artifacts (data not shown), probably resulting from extensive hairpins in this region (Wood et al., 1996). Instead, the NR2A RT-PCR was targeted to the NR2A open reading frame (ORF).

The pHex 9000 vectors expressing antisense and related control constructs were then transiently transfected into NR2A-EYFP and NR2D-EYFP stable cell lines. By using the pHex 9000 vectors to express the antisense and control constructs, the successfully transfected cells were marked with DsRed1. Through flow cytometry, this gated DsRed1 population was separated from the much larger population of untransfected cells in the transient 

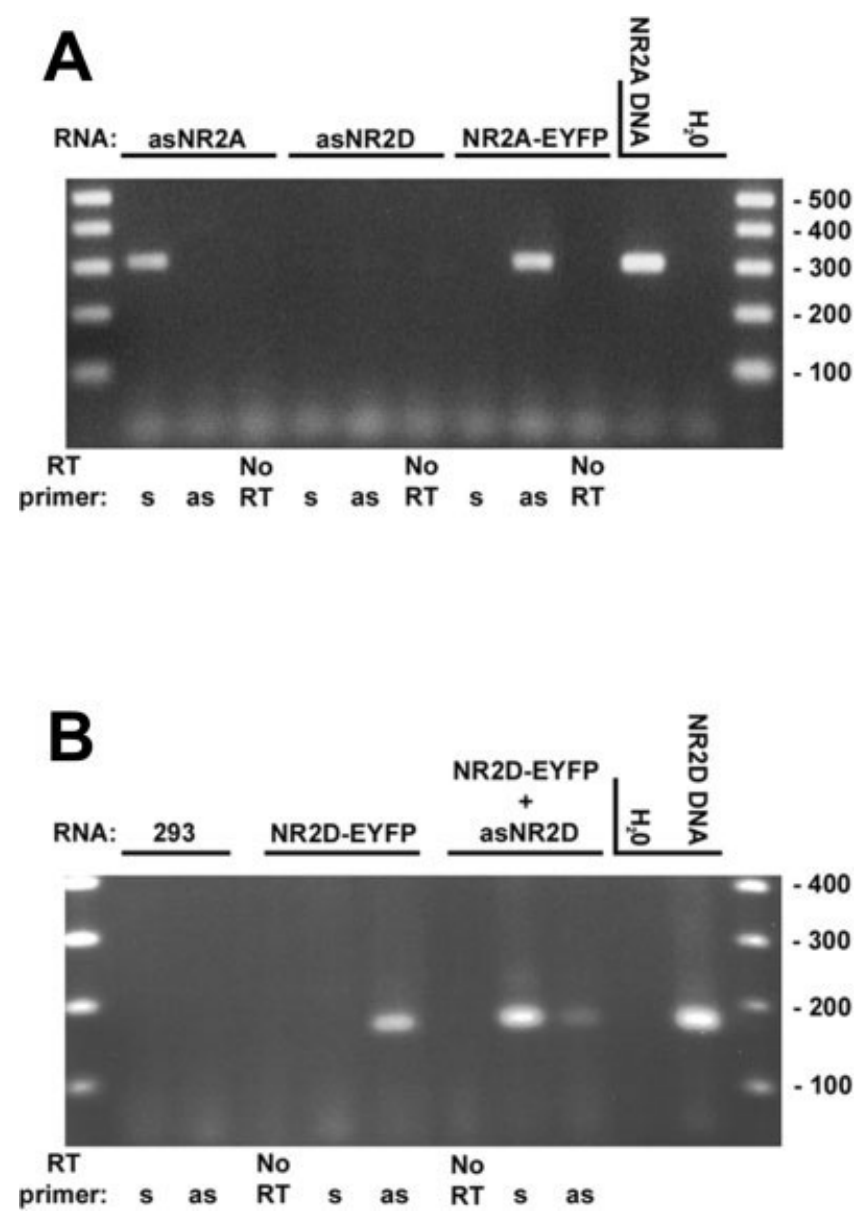

Fig. 4. Antisense constructs are expressed. RT-PCR was carried out to verify RNA expression of asNR2A (A) and asNR2D (B), which were the most effective antisense constructs. Expression of NR2A-EYFP (A) and NR2D-EYFP (B) mRNAs from the stable cell lines was also assessed. Note that primers in sense orientation prime RT of RNA in antisense orientation and vice versa.

expression assay, as the mean channel fluorescence of the stably expressed NR2A-EYFP or NR2D-EYFP in the total ungated cell population was not affected significantly by transfection with any pHex 9000 control or antisense constructs (data not shown). In this way, the signal was separated effectively from the noise (exemplified by Fig. $5 \mathrm{~A}, \mathrm{~B})$. The effect of the various $\mathrm{pHex} 9000$ constructs on gated mean EYFP fluorescence levels in the NR2A-EYFP and NR2D-EYFP cell lines was quantified using this approach (Fig. 5C,D). The most effective construct was asNR2A, which reduced NR2A-EYFP expression by $\sim 55 \%$ in the overexpressing cell line after $48 \mathrm{hr}(P<$ 0.001 vs. controls, $n=12$ ). The smaller construct, asNR2A2, was considerably less effective, reducing NR2A-EYFP expression by $\sim 35 \%$ ( $P<0.001$ vs. controls, $n=12$ ). The asNR2D construct was also effective against its NR2D target; asNR2D reduced the expression of NR2D-EYFP by $\sim 35 \%(P<0.001, n=14)$ with no effect on NR2A-EYFP fluorescence levels, demonstrating the specificity of asNR2D for its target. Likewise, asNR2A and asNR2A2 had no effect on NR2D-EYFP expression, suggesting that the effects of these constructs were highly specific for their corresponding NR2A target.

\section{NR2A-EYFP and NR1-C02'-EYFP Form Functional, Excitotoxic Channels}

Co-expression of fluorescently tagged NR1 and NR2A proteins led to an association between the two proteins that was confirmed using both epifluorescence microscopy and co-immunoprecipitation (Holmes et al., 2002b; Fig. 6A). NR2A-EYFP and NR1-C02'-EYFP could not be co-expressed in the absence of NMDAR antagonists, as the resultant excitotoxicity rapidly deleted co-expressing cells in complete media. Using flow cytometry, we tracked the resultant cell death by incubating transfected cells with PI, which fluoresces in the red (FL2) channel. As shown in Figure 6B, transient transfection of NR2A-EYFP into the NR1-C02'-EYFP stable cell line increased the proportion of cells that failed to exclude the vital stain PI by approximately threefold versus EYFP alone after $24 \mathrm{hr}(P<0.001, n=5)$. The NMDAR antagonist APV $(25 \mu \mathrm{M})$ had no effect on this cell death $(P>0.05, n=5)$; however, increasing the APV dose to $100 \mu \mathrm{M}$ resulted in a significant reduction in the proportion of dead cells $(P<0.05, n=5)$. The noncompetitive NMDAR antagonist ketamine $(100 \mu \mathrm{M})$ abolished excitotoxic cell death such that the percentage of PI-positive cells was not significantly different from the EYFP transfection controls (Fig. 6C; $P<0.001, n=4$ ). In contrast, transfection of NR2D-EYFP did not lead to excitotoxicity $(P>0.05, n=4)$. This is compatible with previous research that indicated that $\mathrm{NR} 2 \mathrm{C}$, which is the protein most highly related to NR2D, also does not generate excitotoxic channels in cultured cells (Anegawa et al., 1995).

Although PI staining did allow us to monitor the excitotoxic cell death associated with co-expression of NR1-4 and NR2A, this procedure had several deficiencies that rendered it less than optimal for evaluating the effects of antisense constructs on NMDAR function. First, the flow cytometer, although highly accurate and objective, underestimates the total number of cells killed via excitotoxicity, as objects that do not fall within the desired forward-scatter and side-scatter limits are discarded from analysis. Thus, cells that are advanced in apoptosis or necrosis are unlikely to be counted, as these cells cannot be distinguished reliably from debris. Secondly, the cell death observed using PI exclusion is not exclusively excitotoxic in nature, as the transfection itself can contribute significantly to observed cell death (e.g., by $\sim 1 / 3$ when pEYFP-N1 is transfected; Fig. 6B). Both of these factors reduce the signal-to-noise ratio of this assay.

To improve the signal-to-noise-ratio associated with our excitotoxicity assay, we again turned to the pHex 9000 vector system to allow antisense vector transfected cells to be tracked directly. Furthermore, the loss of red fluorescence in the transfected cell population could be used as an indicator of cell death, similar to that shown previously using GFP (Anegawa et al., 2000). Transfection 

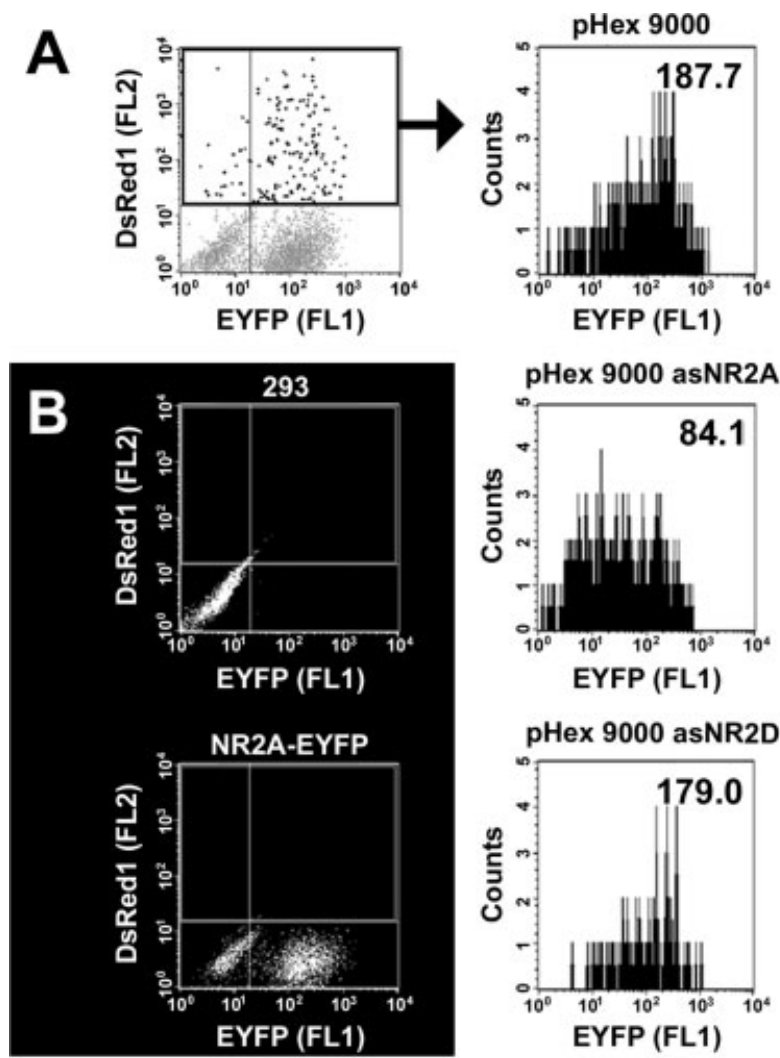
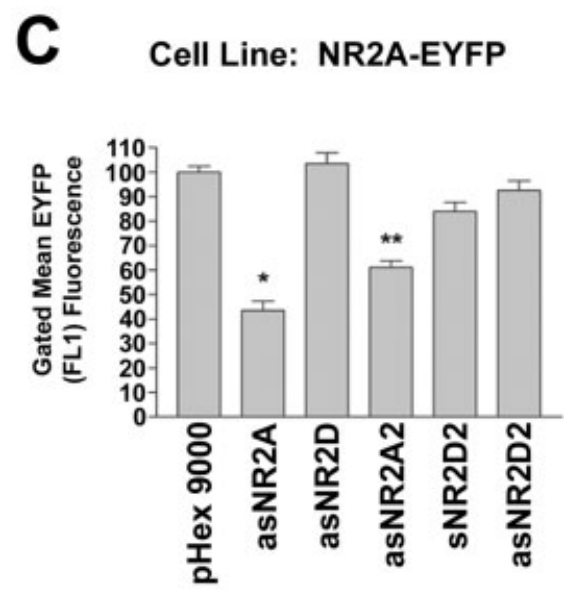

D

\section{Cell Line: NR2D-EYFP}

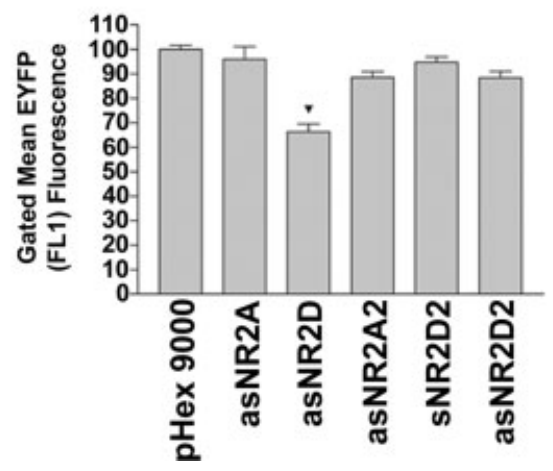

Fig. 5. Flow cytometric analysis of antisense effects. To demonstrate the methodology used to evaluate antisense construct effectiveness, stable NR2A-EYFP cells were transfected with pHex 9000 vectors that were either empty or contained antisense constructs (e.g., pHex 9000 asNR2A, pHex 9000 asNR2D; A). After 48 hr, cells were harvested and subjected to flow cytometric analysis and DsRed1 (FL2)-positive cells were gated. The mean EYFP (FL1) fluorescence intensity of the gated cells was then quantified (displayed in the histograms; arbitrary units). Untransfected 293 cells or stable NR2A-EYFP cells were used

of the NR1-C02'-EYFP stable cell line with the pHex 9000 vector led consistently to expression of DsRed1 in approximately $20 \%$ of the cells. This percentage was unaffected by the presence of $100 \mu \mathrm{M}$ ketamine (Fig. 6D; $P>0.05, n=4)$. In contrast, when NR2A was expressed from the pHex 9000 vector, the percentage of cells expressing DsRed1 was reduced significantly by $\sim 2 / 3$ after $48 \mathrm{hr}$ (Fig. 6D; $P<0.001, n=4$ ). Administration of ketamine restored the percentage of DsRed1-expressing cells to levels that were indistinguishable from the vector controls (Fig. 6D; $P>0.05, n=4$ ). A similar relationship was observed when NR1-4 was expressed from the pHex 9300 vector, and transfected into the NR2A-EYFP stable cell line (Fig. 6E; $P<0.001, n=4$ ). as negative controls to set the gates $(\mathbf{B})$. Using this methodology, the mean EYFP (FL1) fluorescence of stable NR2A-EYFP cells (C) or stable NR2D-EYFP cells (D) transfected with various pHex 9000 constructs was quantified. Values are displayed on a relative scale $(100=$ mean EYFP fluorescence of pHex 9000 transfected cells; $0=$ mean EYFP fluorescence of untransfected 293 cells). Error bars $=$ SEM ( $\star_{\text {significantly different vs. controls, } P<0.001 ; \star \star}{ }^{*} P 0.001$ vs. controls; $P<0.05$ vs. pHex 9000 asNR2A; $\boldsymbol{\nabla} P<0.001$ vs. all others, $n=14)$.

\section{asNR2A Reduces NMDAR-Mediated Excitotoxicity in NR2A Protein-Limiting Conditions}

To demonstrate that asNR2A could reduce NMDAR excitotoxicity, asNR2A was expressed from the pHex 5000 vector. Accordingly, pHex 5000, pHex 5000 asNR2A, or pHex 5000 asNR2D were transfected into the NR1-C02'-EYFP stable cell line (Figs. 7 and 8) or the NR2A-EYFP stable cell line (Fig. 8). Each stable cell line was also transfected with a pHex 9000 or pHex 9300 vector (not shown) that co-expressed the complementary NMDAR subunit along with DsRed1. The data presented in Figure 7 is one of the replicates taken from the combined data of Figure 8 (6:1 ratio) as a means to illustrate 
Fig. 6. Characterization of exaggerated NMDAR activity via analysis of excitotoxicity. A: An antibody specific for the $\mathrm{N}$-terminus of NR2A was used to coimmunoprecipitate bound NR1-C02EYFP to confirm its interaction with NR2A-EYFP; 293 cells, and 293 cells expressing NR1-C02'-EYFP, were loaded as negative and positive controls, respectively. B: NR1-C02'-EYFP cells were transfected with EYFP, or NR2AEYFP in the presence or absence of the competitive NMDAR antagonist APV. After $24 \mathrm{hr}$, cells were harvested, treated with PI to mark nonviable cells, and analyzed via flow cytometry. The percentage of PI (FL2)-positive cells was quantified. C: A similar experiment was carried out using the non-competitive NMDAR antagonist ketamine. D: NR1C02'-EYFP cells were transfected with pHex 9000, pHex 9000 NR2A, or NR2A-DsRed1 in the presence or absence of $100 \mu \mathrm{M}$ of the non-competitive NMDAR antagonist ketamine. After $48 \mathrm{hr}$, cells were harvested and analyzed via flow cytometry. The percentage of DsRed1 (FL2)-positive cells was quantified. E: A similar experiment was carried out on the NR2A-EYFP cell line. Error bars $=$ SEM ( $\star$ significantly different vs. all except $\star \star, P<0.001 ; \star \star P<0.05$ vs. ${ }^{\star}$, $P<0.001$ vs. all others, $n=5 ; \star \star \star P<$ 0.001 vs. EYFP controls, $n=4 ; \boldsymbol{\nabla} P<$ 0.001 vs. all others, $n=4 ; \boldsymbol{\nabla} \nabla P<0.001$ vs. all others, $n=4)$.

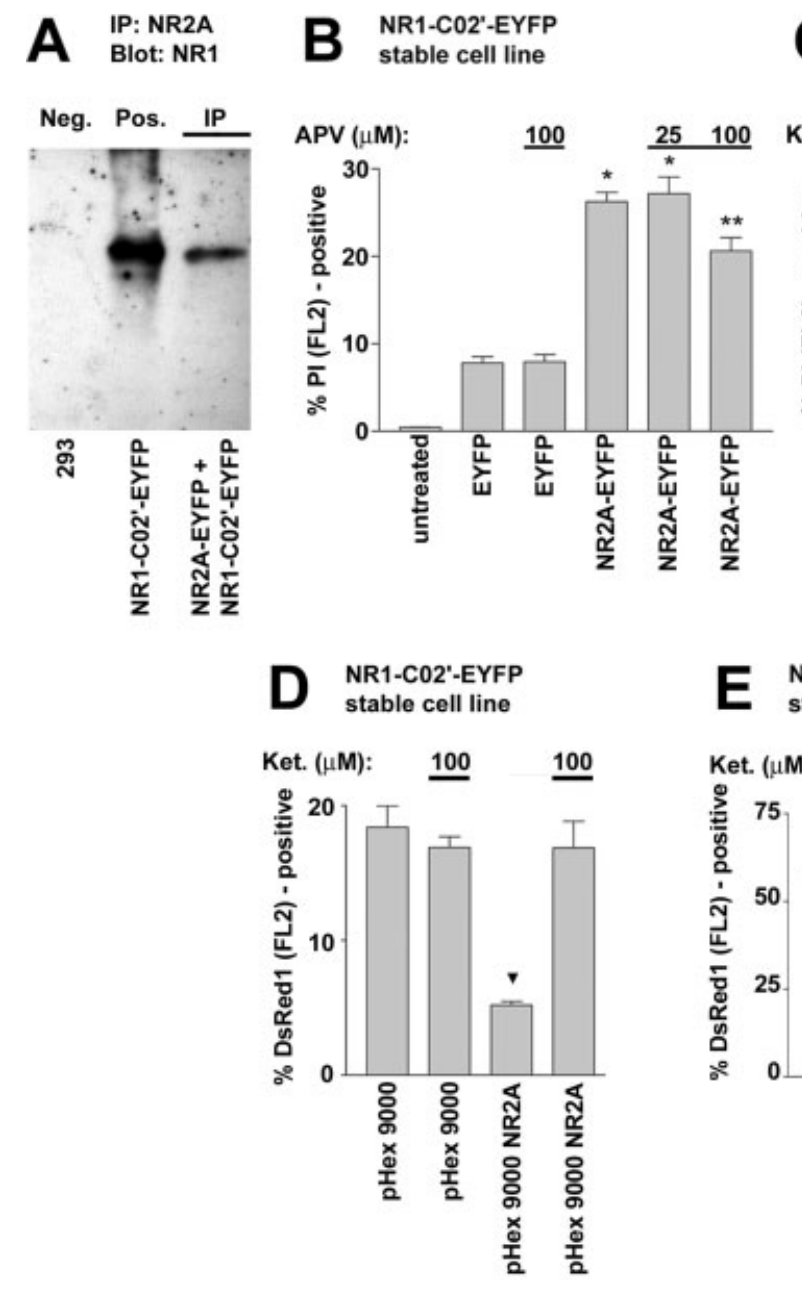

NR1-C02'-EYFP
stable cell line
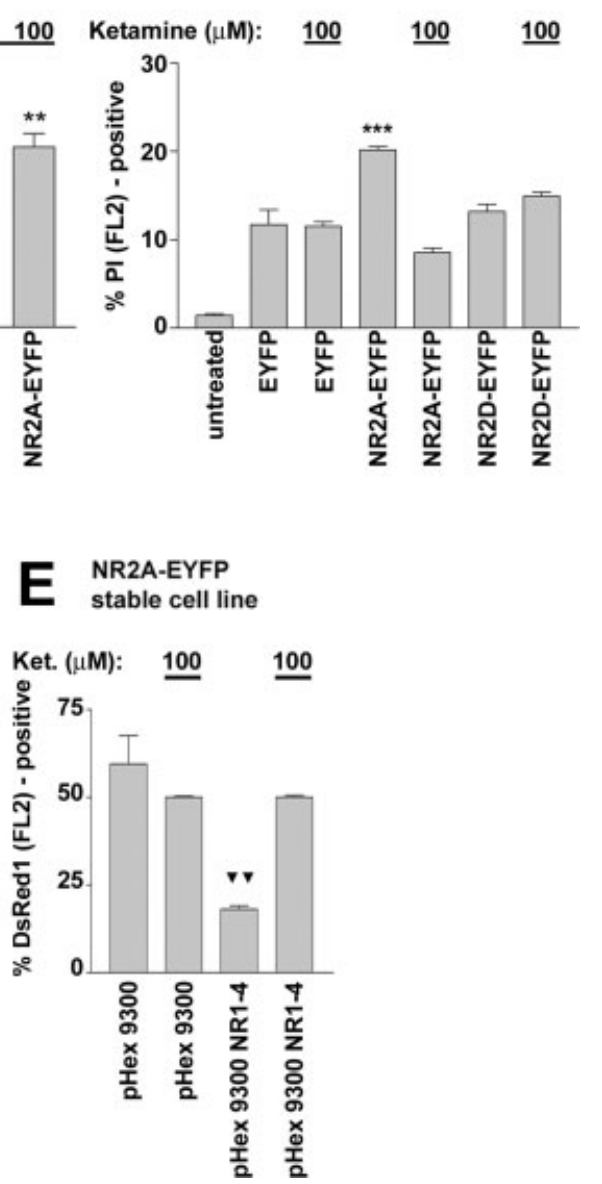

how the excitotoxicity assay works. Because ketamine fully protects cells from excitotoxicity (Fig. 6B,E), the percentage of ketamine-treated cells expressing DsRed1 for a given transfection was defined experimentally as $100 \%$ protection (Fig. 7, left panels). Conversely, as illustrated in Figure 6, it was assumed that in the absence of an asRNA, cells would not be protected from excitotoxicity and therefore the percentage of surviving cells $48 \mathrm{hr}$ posttransfection expressing DsRed1 was defined experimentally as $0 \%$ protection. Using this relative scale, the performance of the pHex 5000 antisense and control vector constructs was assessed. In the presence of the control empty vector pHex 5000 , only $42 \%$ of the transfected population of the DsRed1-expressing cells survived in the absence of ketamine and was equivalent to $0 \%$ protection (Fig. 7A). In contrast pHex asNR2a maintained $86 \%$ of the DsRed1-positive cell population found in the presence of ketamine (Fig. 7B) and thus a 50\% level of protection was achieved. pHex asNR2D (Fig. 7C) could maintain only $53 \%$ of the DsRed1-positive cell population found when ketamine was present or $14 \%$ protection for this experiment.

Using this assay, a dose-response experiment was carried out to see how effective the asNR2A was in reducing excitotoxicity under conditions where NR2A was limiting or in excess at the time that asNR2A was expressed. The NR1-C02'-EYFP cell line (Fig. 8A) was co-transfected at a 2:1 ratio of pHex 5000 asNR2A to pHex 9000 NR2A, which led to levels of DsRed1expressing cells that were no different from cells treated with pHex 5000 or pHex 5000 asNR2D after $48 \mathrm{hr}(P>$ $0.05, n=8$;). When the ratio was increased to $6: 1$, however, pHex 5000 asNR2A increased the percentage of DsRed1-expressing cells to $\sim 80 \%$; a significant increase versus pHex 5000 or pHex 5000 asNR2D $(P<0.05, n=$ $6)$. This percentage of cells was not significantly different from cells treated with a pHex 9000 vector that did not co-express NR2A $(P>0.05, n=6)$. In contrast, a 6:1 ratio of pHex 5000 asNR2A to pHex 9300 NR1-4 was no more effective than pHex 5000 or pHex 5000 asNR2D in the NR2A-EYFP cell line.

\section{DISCUSSION}

To identify and evaluate effective antisense constructs, we developed EYFP-tagged NMDAR subunits that allow protein expression to be tracked using fluorescence microscopy and flow cytometry. It is possible that the fusion of EYFP to the NR2 subunit may alter the 

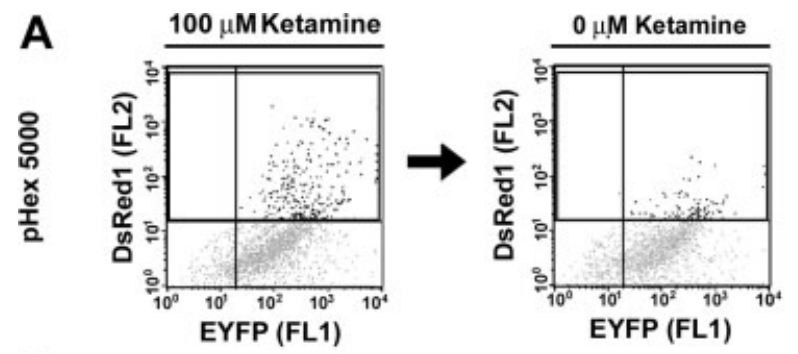

Perçent Survival

Relațive Protection

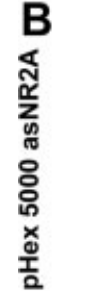

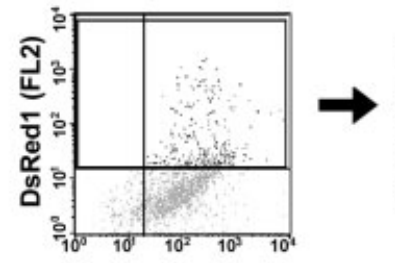

$\operatorname{EYFP}(F L 1)$

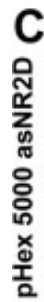
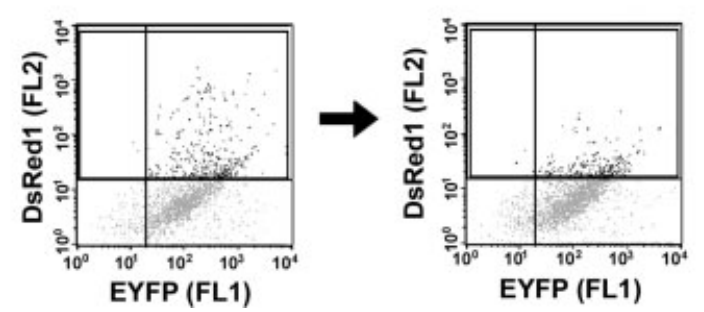

$42 \%$

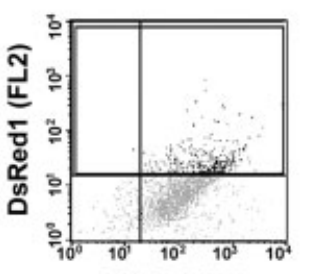

EYFP (FL1)

$86 \%$
$53 \%$

stability or folding of the resultant protein. We have described previously an EGFP-tagged NR1-4 subunit with this deficiency (Holmes et al., 2002a). To characterize stability of the tagged NMDAR 1 and 2 subunits used in this study, we treated stably transfected cell lines expressing these proteins with the protein synthesis blocker cycloheximide and monitored the decay of the protein pool using EYFP fluorescence. Although we could not use this methodology to directly compare half-lives of EYFPtagged subunits with unadulterated NMDAR subunits, the observed values were generally similar to previously reported values for NR1 and NR2A turnover (Huh and Wenthold, 1999; Holmes et al., 2002a). Endogenously expressed NMDAR subunits are synthesized in an environment containing a multitude of binding partners and other NMDAR subunits. Neuronal expression levels are also likely to be considerably lower than those found in our overexpressing cell lines. These differences may account for the somewhat faster turnover of NR2A-EYFP versus endogenously expressed NR2A (Huh and Wenthold, 1999). We also assessed the functional competence of the subunits using excitotoxicity upon coexpression with the necessary NMDAR subunit partner. NR2A-EYFP formed functional channels upon coexpression with NR1-C02'-EYFP that led to cell death that was blocked by NMDAR antagonists.

The use of fluorescent proteins and flow cytometry to track the expression of NMDAR subunits and antisense constructs had several advantages over more conventional approaches. Besides allowing living cells to be analyzed without processing, the EYFP-tagged constructs greatly simplified the production of stable cell lines. The stable cell lines were demonstrably homogeneous in expression quality and quantity. Little variation was observed in the percentage of cells expressing EYFP, or the EYFP fluorescence intensity of the cells from replicate to replicate within a given experiment.

The flow cytometry-based assays developed for this study also increase the signal-to-noise ratio more than that with traditional assays. Antisense effects on NR2A or NR2D protein expression could have been characterized and quantified using Western blots. Although this procedure is highly effective when soluble oligonucleotides are employed, transfection efficiencies of the antisense vectors were typically low. Thus, the much larger population of untransfected cells would obscure the activity of an antisense construct. For example, a construct that could reduce protein expression by $50 \%$, when transfected into $20 \%$ of the cells, would theoretically reduce the total protein yield by only $10 \%$. Besides being difficult to detect by densitometry, this $10 \%$ would underestimate the true effectiveness of a construct by fivefold. Thus, the use of immunological techniques to monitor changes in subunit expression would not have allowed cells transfected (the signal) to be identified easily and separated from untransfected cells (the noise). Transfection-to-transfection variation can also be problematic. The variation in the percentage of transfected cells, as well as the intensity of transfected cells can vary considerably in transient transfections. Because the mean fluorescence intensity is insen- 


\section{A Cell Line: NR1-C02'-EYFP}

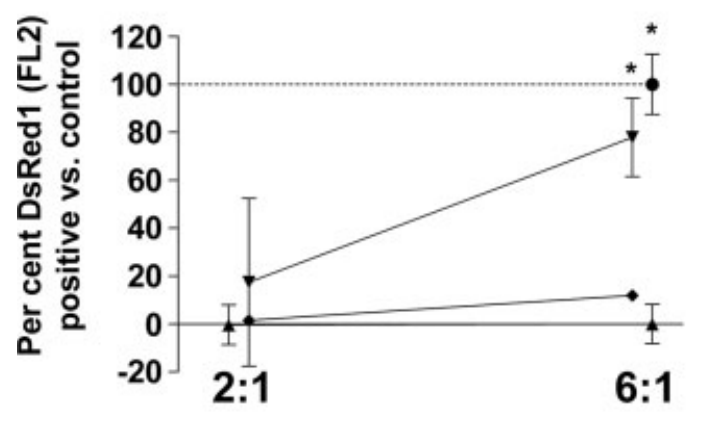

Antisense:Sense ratio

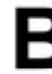

\section{Cell Line: NR2A-EYFP}
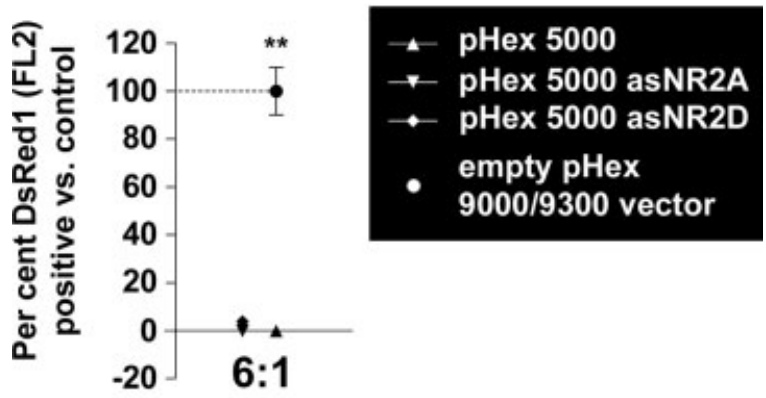

Antisense:Sense ratio

Fig. 8. asNR2A reduces NMDAR excitotoxicity where NR2A is limiting. Using the methodology outlined in the text and Figure7, NR1-C02'-EYFP cells (A) or NR2A-EYFP cells $(\mathbf{B})$ were transfected with pHex 9000 NR2A (A) or pHex 9300 NR1-4 (B), respectively, along with pHex 5000 control or antisense constructs. Each transfection was applied to a set of wells that received $100 \mu \mathrm{M}$ of the noncompetitive NMDAR antagonist ketamine, and a set of wells that did not. For each transfection, the expression of DsRed1 in the absence of ketamine was then normalized against its ketamine control (see text). Empty pHex 9000 or pHex 9300 vectors were also transfected into the cell lines as negative controls. The ratio of pHex 5000 construct DNA (antisense) to pHex 9000 NR2A (A) or pHex 9300 NR1-4 (B) DNA (sense) in each cell line is indicated. Error bars $=$ SEM ( $\star$ significantly different vs. all others, $P<0.05, n=6$; $\star \star P<0.05$ vs. all others, $n=$ $6)$.

sitive to the total numbers of cells gated, the antisense assay is much more resistant to transfection-to-transfection variation.

Likewise, the functional assays were improved by using flow cytometry to track the expression of NMDAR subunits. Previous characterizations of NMDARmediated excitotoxicity have transiently co-expressed NR1 and NR2 (Anegawa et al., 1995, 2000), and used a third plasmid expressing GFP to mark transfected cells (Anegawa et al., 2000). The loss of GFP expression in the absence of NMDAR antagonists was then interpreted as an index of excitotoxicity. The considerable variation observed using our transient transfection system would have limited the effectiveness, and especially the resolution of this approach. Stable expression of NMDAR subunits, as well as the ability to specifically track each subunit, allows transfection variability to be minimized and nonexcitotoxic cell death to be excluded. These improvements significantly enhanced the signal-to-noise ratio of our assay, allowing us to resolve the effects of antisense constructs in reducing NMDAR function.

The reduction in exaggerated NMDAR activity as a result of asNR2A expression seemed to occur only where NR2A levels were limiting. In the NR1-C02'-EYFP cell line, the amount of vector DNA for the antisense construct had to be at least sixfold greater than the NR2A target. In the NR2A-EYFP cell line, NR2A levels are likely in great excess. Thus, whereas $1 \mu \mathrm{g}$ of asNR2A DNA reduces NR2A-EYFP expression in the stable cell line by more than $50 \%$ after $48 \mathrm{hr}$, the remaining protein is sufficient to generate excitotoxic levels of NMDARs. These data likely reflect the requirement for an excess of antisense RNA in comparison to its target mRNA in order for asNR2A to be effective. Although this seems to limit the utility of asNR2A to these specific conditions, it must be stressed that the artificial expression conditions that were amenable to intervention with asNR2A are in line with endogenous NMDAR expression conditions in vivo; namely, where NR2 expression levels are limiting for channel formation (Goebel and Poosch, 1999; Huh and Wenthold, 1999; Prybylowski et al., 2002). Furthermore, the reduction in NMDAR hyperexcitability using asNR2A is more desirable than blocking the function of NMDAR entirely, which would have negative consequences on normal synaptic transmission. Thus, even if only a $50 \%$ reduction of NR2A expression is achieved, it may be sufficient to prevent or reduce pathologies associated with NMDAR hyperexcitability.

NMDAR antagonists have obvious utility for treating transient NMDAR pathology, such as in ischemia or CNS trauma, as transient, global application of antagonists does not interfere with the important cognitive functions of NMDARs over the long term. For autonomic dysreflexia and chronic pain syndromes associated with spinal cord injury, however, sustained, global administration of antagonists leads to profound side effects (Doble, 1999; Hewitt, 2000) that can be as bad or worse than the original conditions (Parsons, 2001). The neurons responsible for these conditions can be transduced selectively by viral vectors derived from herpes simplex virus type-1 (LeVatte et al., 1997, 1998; Wilson et al., 1999). Thus, one way to deliver an anti-NMDAR therapeutic agent more selectively to the neurons responsible for disease would be through the use of such a vector. Accordingly, we focused on developing an antisense NR2A gene, because NR2s are limiting for channel formation. As well, NR2A is the most excitotoxic NR2 subunit (Anegawa et al., 1995), and contributes to chronic pain in vivo (Minami et al., 1997). Thus NR2A containing NMDAR are likely to be partic- 
ularly hyperexcitable. Although vectors expressing antisense genes targeted to NR1 have been described previously (Finegold et al., 2001; Cheli et al., 2002), no such construct has yet been developed for any NR2 subunit.

The antisense constructs generated in this study were produced using simple directional cloning technology. We favored the generation of larger, highly specific constructs that would be suitable for delivery using a viral vector. Within the ORFs of NR2A and NR2D, the sequences share $58.8 \%$ identity. Thus, because the antisense constructs did not affect expression of nonspecific target proteins, asNR2A and asNR2D are highly specific for their target mRNAs. The smaller constructs that we developed were less effective or not effective as determined using our assays. The presence of secondary structures within the 5'UTR of NR2A (Wood et al., 1996) might have contributed to the reduced effectiveness of the smaller asNR2A2 construct. Further refinement of our antisense construct should be possible, and could be accomplished readily using our assays. Our assays can also be extended to test small interfering (si)RNAs (Shi, 2003) and dominant negative mutants (Holmes et al., 2002a). The development of rapid and effective assays for evaluating constructs that interfere with NMDAR function has allowed the conditions required for construct effectiveness to be identified and characterized, and should greatly improve further optimization.

\section{ACKNOWLEDGMENTS}

We thank M. Bielas for her technical assistance and help. This work was supported in part by studentships from the Ontario Neurotrauma Foundation (P.M.) and CIHR (K.H.).

\section{REFERENCES}

Anegawa NJ, Guttmann RP, Grant ER, Anand R, Lindstrom J, Lynch DR. 2000. N-methyl-D-aspartate receptor mediated toxicity in nonneuronal cell lines: characterization using fluorescent measures of cell viability and reactive oxygen species production. Brain Res Mol Brain Res 77: 163-175.

Anegawa NJ, Lynch DR, Verdoorn TA, Pritchett DB. 1995. Transfection of N-methyl-D-aspartate receptors in a nonneuronal cell line leads to cell death. J Neurochem 64:2004-2012.

Baker BF, Monia BP. 1999. Novel mechanisms for antisense-mediated regulation of gene expression. Biochim Biophys Acta 1489:3-18.

Bliss TV, Collingridge GL. 1993. A synaptic model of memory: long-term potentiation in the hippocampus. Nature 361:31-39.

Cheli VT, Adrover MF, Blanco C, Rial Verde E, Guyot-Revol V, Vidal R, Martin E, Alche L, Sanchez G, Acerbo M, Epstein AL, Jerusalinsky D. 2002. Gene transfer of NMDAR1 subunit sequences to the rat CNS using herpes simplex virus vectors interfered with habituation. Cell Mol Neurobiol 22:303-314.

Chenu C, Serre CM, Raynal C, Burt-Pichat B, Delmas PD. 1998. Glutamate receptors are expressed by bone cells and are involved in bone resorption. Bone 22:295-299.

Ciabarra AM, Sullivan JM, Gahn LG, Pecht G, Heinemann S, Sevarino KA. 1995. Cloning and characterization of chi-1: a developmentally regulated member of a novel class of the ionotropic glutamate receptor family. J Neurosci 15:6498-6508.

Crooke ST. 1999. Molecular mechanisms of action of antisense drugs. Biochim Biophys Acta 1489:31-44.
Cull-Candy S, Brickley S, Farrant M. 2001. NMDA receptor subunits: diversity, development and disease. Curr Opin Neurobiol 11:327-335.

Dingledine R, Borges K, Bowie D, Traynelis SF. 1999. The glutamate receptor ion channels. Pharmacol Rev 51:7-61.

Doble A. 1999. The role of excitotoxicity in neurodegenerative disease: implications for therapy. Pharmacol Ther 81:163-221.

Eide PK. 1998. Pathophysiological mechanisms of central neuropathic pain after spinal cord injury. Spinal Cord 36:601-612.

Faden AI, Demediuk P, Panter SS, Vink R. 1989. The role of excitatory amino acids and NMDA receptors in traumatic brain injury. Science 244:798-800.

Finegold AA, Perez FM, Iadarola MJ. 2001. In vivo control of NMDA receptor transcript level in motoneurons by viral transduction of a short antisense gene. Brain Res Mol Brain Res 90:17-25.

Fukaya M, Kato A, Lovett C, Tonegawa S, Watanabe M. 2003. Retention of NMDA receptor NR2 subunits in the lumen of endoplasmic reticulum in targeted NR1 knockout mice. Proc Natl Acad Sci USA 100:48554860 .

Garcia-Gallo M, Renart J, Diaz-Guerra M. 2001. The NR1 subunit of the $\mathrm{N}$-methyl-D-aspartate receptor can be efficiently expressed alone in the cell surface of mammalian cells and is required for the transport of the NR2A subunit. Biochem J 356:539-547.

Goebel DJ, Poosch MS. 1999. NMDA receptor subunit gene expression in the rat brain: a quantitative analysis of endogenous mRNA levels of NR1Com, NR2A, NR2B, NR2C, NR2D and NR3A. Brain Res Mol Brain Res 69:164-170.

Guttmann RP, Baker DL, Seifert KM, Cohen AS, Coulter DA, Lynch DR. 2001. Specific proteolysis of the NR2 subunit at multiple sites by calpain. J Neurochem 78:1083-1093.

Hewitt DJ. 2000. The use of NMDA-receptor antagonists in the treatment of chronic pain. Clin J Pain 16(Suppl):73-79.

Holmes KD, Cassam AK, Chan B, Peters AA, Weaver LC, Dekaban GA. 2000. A multi-mutant herpes simplex virus vector has minimal cytotoxic effects on the distribution of filamentous actin, alpha-actinin 2 and a glutamate receptor in differentiated PC12 cells. J Neurovirol 6:33-45.

Holmes KD, Mattar PA, Marsh DR, Weaver LC, Dekaban GA. 2002a. The N-methyl-D-aspartate receptor splice variant NR1-4 C-terminal domain. Deletion analysis and role in subcellular distribution. J Biol Chem 277:1457-1468.

Holmes KD, Mattar P, Marsh DR, Jordan V, Weaver LC, Dekaban GA. 2002b. The C-terminal C1 cassette of the N-methyl-D-aspartate receptor 1 subunit contains a bi-partite nuclear localization sequence. J Neurochem 81:1152-1165.

Huh KH, Wenthold RJ. 1999. Turnover analysis of glutamate receptors identifies a rapidly degraded pool of the $N$-methyl-D-aspartate receptor subunit, NR1, in cultured cerebellar granule cells. J Biol Chem 274:151157.

Inagaki N, Kuromi H, Gonoi T, Okamoto Y, Ishida H, Seino Y, Kaneko T, Iwanaga T, Seino S. 1995. Expression and role of ionotropic glutamate receptors in pancreatic islet cells. FASEB J 9:686-691.

Ishii T, Moriyoshi K, Sugihara H, Sakurada K, Kadotani H, Yokoi M, Akazawa C, Shigemoto R, Mizuno N, Masu M, Nakanishi S. 1993. Molecular characterization of the family of the N-methyl-Daspartate receptor subunits. J Biol Chem 268:2836-2843.

Jarvis TC, Wincott FE, Alby LJ, McSwiggen JA, Beigelman L, Gustofson J, DiRenzo A, Levy K, Arthur M, Matulic-Adamic J, Karpeisky A, Gonzalez C, Woolf TM, Usman N, Stinchcomb DT. 1996. Optimizing the cell efficacy of synthetic ribozymes. Site selection and chemical modifications of ribozymes targeting the proto-oncogene c-myb. J Biol Chem 271:29107-29112.

Kohl BK, Dannhardt G. 2001. The NMDA receptor complex: a promising target for novel antiepileptic strategies. Curr Med Chem 8:1275-1289.

Laemmli UK. 1970. Cleavage of structural proteins during the assembly of the head of bacteriophage T4. Nature 227:680-685. 
LeVatte MA, Cassam AK, Dekaban GA, Weaver LC. 1998. Analysis of a multi-mutant herpes simplex virus type 1 for gene transfer into sympathetic preganglionic neurons and a comparison to adenovirus vectors. Neuroscience 86:1321-1336.

LeVatte MA, Dekaban GA, Weaver LC. 1997. Gene transfer into sympathetic preganglionic neurons in vivo using a non-replicating thymidine kinase-deficient herpes simplex virus type 1. Neuroscience 80:893-906.

Lieberman DN, Mody I. 1999. Casein kinase-II regulates NMDA channel function in hippocampal neurons. Nat Neurosci 2:125-132.

Lloyd BH, Giles RV, Spiller DG, Grzybowski J, Tidd DM, Sibson DR. 2001. Determination of optimal sites of antisense oligonucleotide cleavage within TNF $\alpha$ mRNA. Nucleic Acids Res 29:3664-3673.

Lombardi G, Dianzani C, Miglio G, Canonico PL, Fantozzi R. 2001. Characterization of ionotropic glutamate receptors in human lymphocytes. Br J Pharmacol 133:936-944.

Luo JH, Fu ZY, Losi G, Kim BG, Prybylowski K, Vissel B, Vicini S. 2002. Functional expression of distinct NMDA channel subunits tagged with green fluorescent protein in hippocampal neurons in culture. Neuropharmacology 42:306-318.

Maiorov DN, Krenz NR, Krassioukov AV, Weaver LC. 1997. Role of spinal NMDA and AMPA receptors in episodic hypertension in conscious spinal rats. Am J Physiol 273:1266-1274.

Malenka RC, Nicoll RA. 1999. Long-term potentiation-a decade of progress? Science 285:1870-1874.

Marshall J, Molloy R, Moss GW, Howe JR, Hughes TE. 1995. The jellyfish green fluorescent protein: a new tool for studying ion channel expression and function. Neuron 14:211-215.

Minami T, Sugatani J, Sakimura K, Abe M, Mishina M, Ito S. 1997. Absence of prostaglandin E2-induced hyperalgesia in NMDA receptor epsilon subunit knockout mice. Br J Pharmacol 120:1522-1526.

Monyer H, Burnashev N, Laurie DJ, Sakmann B, Seeburg PH. 1994. Developmental and regional expression in the rat brain and functional properties of four NMDA receptors. Neuron 12:529-540.

Morikawa E, Mori H, Kiyama Y, Mishina M, Asano T, Kirino T. 1998. Attenuation of focal ischemic brain injury in mice deficient in the epsilon1 (NR2A) subunit of NMDA receptor. J Neurosci 18:9727-9732.

Nishi M, Hinds H, Lu HP, Kawata M, Hayashi Y. 2001. Motoneuronspecific expression of NR3B, a novel NMDA-type glutamate receptor subunit that works in a dominant-negative manner. J Neurosci 21:185.

Nishizawa Y. 2001. Glutamate release and neuronal damage in ischemia. Life Sci 69:369-381.

Ozawa S, Kamiya H, Tsuzuki K. 1998. Glutamate receptors in the mammalian central nervous system. Prog Neurobiol 54:581-618.

Parsons G. 2001. NMDA receptors as targets for drug action in neuropathic pain. Eur J Pharm 429:71-78.

Pierce ML, Ruffner DE. 1998. Construction of a directed hammerhead ribozyme library: towards the identification of optimal target sites for antisense-mediated gene inhibition. Nucleic Acids Res 26:5093-5101.

Prybylowski K, Fu Z, Losi G, Hawkins LM, Luo J, Chang K, Wenthold
RJ, Vicini S. 2002. Relationship between availability of NMDA receptor subunits and their expression at the synapse. J Neurosci 22:8902-8910. Sasaki YF, Rothe T, Premkumar LS, Das S, Cui J, Talantova MV, Wong HK, Gong X, Chan SF, Zhang D, Nakanishi N, Sucher NJ, Lipton SA. 2002. Characterization and comparison of the NR3A subunit of the NMDA receptor in recombinant systems and primary cortical neurons. J Neurophysiol 87:2052-2063.

Scherr M, Reed M, Huang CF, Riggs AD, Rossi JJ. 2000. Oligonucleotide scanning of native mRNAs in extracts predicts intracellular ribozyme efficiency: ribozyme-mediated reduction of the murine DNA methyltransferase. Mol Ther 2:26-38.

Sheng M, Kim MJ. 2002. Postsynaptic signaling and plasticity mechanisms. Science 298:776-780.

Shi Y. 2003. Mammalian RNAi for the masses. Trends Genet 19:9-12. Sohail M, Hochegger H, Klotzbucher A, Guellec RL, Hunt T, Southern EM. 2001. Antisense oligonucleotides selected by hybridisation to scanning arrays are effective reagents in vivo. Nucleic Acids Res 29:20412051.

Sprengel R, Single FN. 1999. Mice with genetically modified NMDA and AMPA receptors. Ann N Y Acad Sci 868:494-501.

Tatout C, Gauthier E, Pinon H. 1998. Rapid evaluation in Escherichia coli of antisense RNAs and ribozymes. Lett Appl Microbiol 27:297-301.

Vazhappilly R, Sucher NJ. 2002. Turnover analysis of N-methyl-Daspartate receptor subunit NR1 protein in PC12 cells. Neurosci Lett 318:153-157.

Wagey R, Hu J, Pelech SL, Raymond LA, Krieger C. 2001. Modulation of NMDA-mediated excitotoxicity by protein kinase C. J Neurochem 78: 715-726.

Wang Y, TesFaye E, Yasuda RP, Mash DC, Armstrong DM, Wolfe BB. 2000. Effects of post-mortem delay on subunits of ionotropic glutamate receptors in human brain. Brain Res Mol Brain Res 80:123-131.

Wilson SP, Yeomans DC, Bender MA, Lu Y, Goins WF, Glorioso JC. 1999. Antihyperalgesic effects of infection with a preproenkephalinencoding herpes virus. Proc Natl Acad Sci USA 96:3211-3216.

Wood MW, VanDongen HM, VanDongen AM. 1996. The 5'untranslated region of the $N$-methyl-D-aspartate receptor NR2A subunit controls efficiency of translation. J Biol Chem 271:8115-8120.

Wrzesinski J, Legiewicz M, Ciesiolka J. 2000. Mapping of accessible sites for oligonucleotide hybridization on hepatitis delta virus ribozymes. $\mathrm{Nu}$ cleic Acids Res 28:1785-1793.

Xing Z, Whitton JL. 1992. Ribozymes which cleave arenavirus RNAs: identification of susceptible target sites and inhibition by target site secondary structure. J Virol 66:1361-1369.

Yu Q, Pecchia DB, Kingsley SL, Heckman JE, Burke JM. 1998. Cleavage of highly structured viral RNA molecules by combinatorial libraries of hairpin ribozymes. The most effective ribozymes are not predicted by substrate selection rules. J Biol Chem 273:23524-23533.

Zhao JJ, Lemke G. 1998. Rules for ribozymes. Mol Cell Neurosci 11:9297. 